\title{
Hubungan Asupan Karbohidrat dan Indeks Massa Tubuh pada Wanita Premenopause dan Postmenopause di Indonesia (Analisis Riskesdas 2010)
}

\section{Rizal Permadi*}

Prodi Gizi Klinik Jurusan Kesehatan Politeknik Negeri Jember

\author{
A R T I C L E I N F O \\ Article history: \\ Received 19 July 2019 \\ Received in revised form \\ 16 August 2019 \\ Accepted 19 September \\ 2019 \\ Available online 30 October \\ 2019 \\ Kata Kunci: \\ indeks massa tubuh, asupan \\ karbohidrat \\ Keywords: \\ body mass index, intake of \\ carbohydrates.
}

\begin{abstract}
A B S T R A K
Pada penelitian ini menganalisa tentang hubungan asupan karbohidrat dan indeks massa tubuh pada wanita premenopause dan postmenopause di Indonesia.Penelitian ini menggunakan data Riskesdas 2010 dengan pendekatan Cross-sectional dan desain survei analitik. Sampel yang didapat adalah 6057 wanita premenopause dan 4787 wanita postmenopause. Analisa data menggunakan uji korelasi Pearson Product Moment dan uji analisis regresi berganda. Hasil penelitian ini menunjukkan karakteristik responden didapatkan wanita premenopause tinggal di wilayah perkotaan sebanyak 3.540 orang dan perdesaan 2.517 orang, sedangkan pada wanita postmenopause tinggal di wilayah perkotaan sebanyak 2.733 orang dan perdesaan 2.054 orang. Rata-rata usia wanita premenopause adalah 46 tahun 8 bulan,dan rata-rata usia wanita postmenopause adalah 51 tahun 7 bulan. Rata-rata indeks massa tubuh wanita premenopause $23,5 \pm 3,6$ $\mathrm{kg}$, asupan karbohidrat $207,3 \pm 67,1 \mathrm{gr}$ dan rata-rata indeks massa tubuh wanita postmenopause $23,32 \pm 3,6 \mathrm{~kg}$, asupan karbohidrat $204,4 \pm 66,5$ gr. Asupan karbohidrat dan indeks massa tubuh berhubungan secara bermakna $(p<0,05)$. Status menopause merupakan variabel terkuat
\end{abstract} yang mempengaruhi indeks massa tubuh pada wanita premenopause dan postmenopause. Karenanya diperlukan penyuluhan tentang pentingnya memperbanyak asupan karbohidrat dan asupan kalsium serta mengurangi asupan lemak untuk mempertahankan berat badan ideal agar terciptanya derajat kesehatan yang baik.

\section{A B S T R A C T}

This research to identify the relationship intake of carbohydrates and body mass index in premenopausal and postmenopausal women in Indonesia. This research used Riskesdas 2010 with a cross-sectional study and analytical survey design. The samples obtained were 6057 premenopausal women and 4787 postmenopausal women. Data analiysis using pearson product moment correlation test and multiple regression analysis test. This research result characteristics of respondents obtained premenopausal women living in urban areas as many as 3,540 people and 2,517 women live in rural, whereas in postmenopausal women live in urban areas as many as 2,733 people and 2,054 women live in rural. The average age of premenopausal women is 46 years and 8 months, and the average age of postmenopausal women is 51 years and 7 months. Average body mass index of premenopausal women is $23.5 \pm 3.6,207.3 \pm 67.1$ grams carbohydrate and average body mass index of postmenopausal women $23.32 \pm 3.6,204.4 \pm 66.5$ grams carbohydrate. Carbohydrate intake and body mass index were significantly associated $(p<0.05)$. Menopausal status was the strongest variable affecting body mass index in premenopausal and postmenopausal women. Therefore the information about the importance of high intake of carbohydrates and calcium intake and reducing fat intake is needed to maintain ideal body weight in order to create a good health status.

Copyright (C) Universitas Pendidikan Ganesha. All rights reserved.

\footnotetext{
* Corresponding author.

E-mail addresses: rizal2204@gmail.com (M Rizal Permadi)
} 


\section{Pendahuluan}

Masyarakat umumnya memahami malnutrisi sebagai kondisi kekurangan karbohidrat, protein, lemak, vitamin dan mineral. Akan tetapi pemahaman malnutrisi juga mencakup suatu kondisi kelebihan zat gizi seperti karbohidrat khususnya gula. Malnutrisi juga berkaitan dengan kurangnya konsumsi serat yang termasuk gula kompleks. Kelebihan konsumsi gula sederhana akan mendorong metabolism tubuh ke arah biosintesis lemak. Penimbunan lemak dapat memberikan implikasi bagi kesehatan diantaranya adalah diabetes mellitus, konstipasi, hipertensi, dan arterosclerosis. Pengetahuan ibu tentang gizi tentunya akan mempengaruhi status gizi keluarga. Menurut Hadi, yang melakukan penelitian di SMA Negeri 9 Semarang [1] mengemukakan bahwa telah terjadi perubahan gaya hidup sehari-hari di masyarakat yaitu terjadi penurunan aktifitas fisik dan kelebihan asupan karbohidrat, protein, lemak dan kurangnya konsumsi serat. Dampak dari keadaan ini adalah kelebihan berat badan dan obesitas pada siswa terdapat kecenderungan menyukai makanan cepat saji dan penurunan aktivitas fisik [2]. Kelebihan zat gizi pada remaja cenderung berlanjut hingga dewasa bahkan lansia. Penyakit yang dipicu oleh gizi lebih adalah penyakit degeneratif seperti kardiovaskuler dan diabetes mellitus (Noriko, 2014).

Negara Indonesia merupakan negara megadiversity, termasuk dalam kekayaan flora (tumbuhan) yang menempatkan Indonesia dalam urutan kelima di dunia. Sehingga Indonesia merupakan salah satu negara penghasil komoditas holtikultura yang cukup penting (Alamendah, 2012). Komoditas holtikultura di Indonesia merupakan salah satu komoditas hasil pertanian yang memiliki nilai ekonomis tinggi. Salah satu pemanfaatannya yaitu dijadikan sebagai bahan pangan untuk memenuhi sumber gizi yang dibutuhkan manusia. Menurut Peraturan Pemerintah RI nomor 28 tahun 2004, pangan adalah segala sesuatu yang berasal dari sumber hayati dan air, baik yang diolah maupun yang tidak diolah, yang diperuntukkan sebagai makanan atau minuman bagi konsumsi manusia. Pengembangan produk pangan melalui aneka bentuk olahan merupakan salah satu cara untuk menambah nilai ekonomi produk pangan (Qalsum, 2015).

Jumlah penduduk Lansia senantiasa mengalami peningkatan seiring dengan makin meningkatnya usia harapan hidup. Indonesia termasuk negara berstruktur tua, dapat dilihat dari persentase pendudukan lansia pada tahun 2008, 2009 dan 2012 telah mencapai lebih dari 7 \%, penduduk lansia tertinggi berjenis kelamin perempuan yaitu sebesar 8,2 \%. Perhitungan statistik memperkirakan di tahun 2020 jumlah penduduk Indonesia akan mencapai 262,6 juta jiwa dengan jumlah perempuan yang hidup dalam usia menopause adalah sekitar 30,3 juta jiwa dan jumlah laki-laki di usia andropause akan mencapai 24,7 juta jiwa (Kemenkes, 2007). Obesitas saat ini sudah menjadi masalah global. Prevalensinya meningkat tidak saja di negara maju tapi juga di negara-negara berkembang. Sebuah penelitian pada wanita di Spanyol menunjukkan obesitas berhubungan dengan munculnya gejala menopause berat, penelitian di Yunani sekitar $44 \%$ wanita postmeopuase memilki berat badan lebih, dari angka tersebut 20 \% nya menderita obesitas ( Fernandez, 2010).

Berdasarkan hasil Riskesdas 2010 bahwa status gizi obesitas lansia pada wanita umur 45 -49 dan 50 - 54 tahun menunjukkan angka yang tertinggi. Dapat dilihat pada obesitas pada wanita lansia umur 45 -49 tahun berdasarkan IMT 21,6\% dan obesitas pada wanita lansia umur 50 - 54 tahun berdasarkan IMT $20,3 \%$. Penelitian yang dilakukan di China menemukan terdapat hubungan yang bermakna antara makanan/minuman manis dengan obesitas pada wanita (Kim, 2008).

\section{Metode}

Penelitian ini menggunakan data sekunder yang bersumber dari hasil Riset Kesehatan Dasar Kementerian Kesehatan Republik Indonesia tahun 2010. Lokasi penelitian meliputi 33 provinsi di Indonesia. Desain penelitian pada Riskesdas 2010 adalah survei berskala besar, potong lintang (crosssectional).Populasi pada penelitian ini adalah semua wanita usia premenopause (45 - 49 tahun) dan postmenopause ( 50 - 54 tahun) di Indonesia. Sedangkan Sampel pada penelitian ini adalah 6057 wanita premenopause usia 45 - 49 tahun dan 4787 wanita postmenopause usia 50 - 54 tahun di Indonesia yang memiliki IMT antara 16 - 35 dan memilki kelengkapan data - data yang menjadi variabel penelitian. Analisis deskriptif dilakukan untuk mengetahui distribusi frekuensi dari variabel yang diteliti dalam penelitian ini variabel-variabel yang diteliti meliputi wilayah, usia, IMT, dan asupan karbohidrat. Analisis Korelasi Pearson Product Moment mencari hubungan variabel bebas (IMT) dengan variabel tak bebas (asupan $\mathrm{KH}$ ). Analisis regresi menemukan model regresi yang paling sesuai untuk menggambarkan faktor-faktor yang berhubungan dengan varibel independen 


\section{Hasil dan pembahasan}

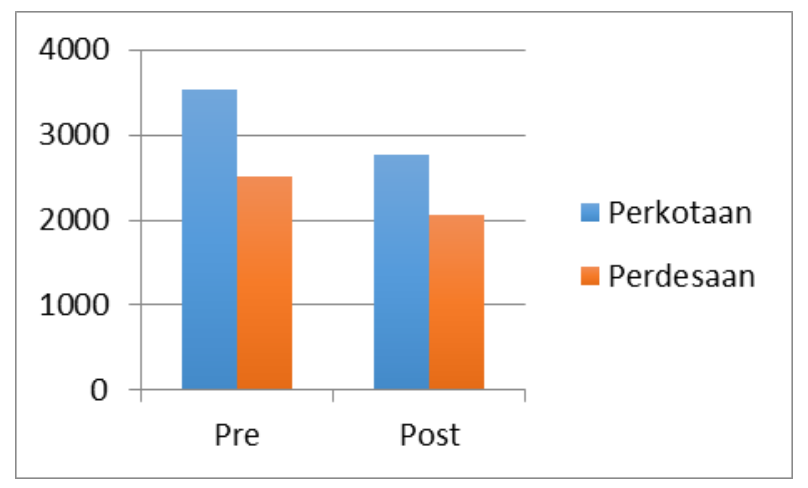

Gambar 1. Grafik Distribusi Wanita Premenopause dan Postmenopause Berdasarkan Wilayah

Pada grafik di atas menunjukkan bahwa distribusi responden premenopause dengan persentase terbesar tinggal di wilayah perkotaan yaitu sebanyak 3.540 orang $(58,44 \%)$ dan di wilayah perdesaan sebanyak 2.517 orang $(41,56 \%)$. Sedangkan responden postmenopause dengan persentase terbesar tinggal di wilayah perkotaan yaitu sebanyak 2.733 orang $(57,09 \%)$ dan di wilayah perdesaan sebanyak 2.054 orang $(42,91 \%)$.

Tabel 1. Usia Wanita Premenopause dan Postmenopause

\begin{tabular}{lcc}
\hline & Pre & Post \\
\hline $\mathrm{N}$ & 6057 & 4787 \\
Mean & 46.81 & 51,76 \\
Median & 47 & 52 \\
Mode & 45 & 50 \\
Std. Deviation & 1.425 & 1.454 \\
Minimum & 45 & 50 \\
Maximum & 49 & 54 \\
\hline
\end{tabular}

Rata-rata umur responden berusia 45 - 49 tahun yaitu 46 tahun 8 bulan \pm 1 tahun 4 bulan. Dari tabel dapat terlihat bahwa usia terendah wanita premenopause 45 tahun dan usia tertinggi wanita premenopause 49 tahun. Sedangkan rata-rata umur responden berusia $50-54$ tahun yaitu 51 tahun 7 bulan \pm 1 tahun 4 bulan. Dari tabel dapat terlihat bahwa usia terendah wanita postmenopause 50 tahun dan usia tertinggi wanita postmenopause 54 tahun.

Tabel 2. Indeks Massa Tubuh Premenopausedan Postmenopause

\begin{tabular}{lll}
\hline IMT & $\begin{array}{l}\text { Pre } \\
(\mathrm{n}=6057)\end{array}$ & $\begin{array}{l}\text { Post } \\
(\mathrm{n}=4787)\end{array}$ \\
\hline Mean & 23.48 & 23.32 \\
Median & 23.10 & 22.90 \\
Mode & 22.0 & 22.0 \\
Std. Deviation & 3.63 & 3.63 \\
Minimum & 16.0 & 16.0 \\
Maximum & 35.0 & 35.0 \\
\hline
\end{tabular}

Berdasarkan tabel di atas dapat diketahui bahwa dari 6057 responden premenopause, rata-rata indeks massa tubuhnya sebesar 23,48 dengan standar deviasi 3,63. Sedangkan responden postmenopause terdiri dari 4787 responden, rata-rata memiliki indeks massa tubuhnya 23,32 dengan standar deviasi 3,63. Kebanyakan wanita premenopause dan postmenopause memiliki IMT sebesar 22. 
Tabel 3. Asupan Karbohidrat Premenopause danPostmenopause

\begin{tabular}{lll}
\hline Asupan KH & $\begin{array}{l}\text { Pre } \\
(\mathrm{n}=6057)\end{array}$ & $\begin{array}{l}\text { Post } \\
(\mathrm{n}=4787)\end{array}$ \\
\hline Mean & 207.25 & 204,04 \\
Median & 202.30 & 198.96 \\
Mode & 97.40 & 197.10 \\
Std. Deviation & 67.12 & 66.43 \\
Minimum & 50.38 & 52.15 \\
Maximum & 399.44 & 399.90 \\
\hline
\end{tabular}

Rata-rata asupan karbohidrat premenopause sebanyak 207,25 gr dengan standar deviasi 67,12 atau 53,96 \% dari total energi. Dari tabel dapat terlihat bahwa asupan karbohidrat terendah premenopause sebanyak 50,38 gr dan asupan karbohidrat tertinggi sebanyak 399,44 gr. Sedangkan dari 4787 responden wanita postmenopause, rata-rata asupan karbohidrat postmenopause sebanyak 204,04 gr dengan standar deviasi 66,43. Dari tabel dapat terlihat bahwa asupan karbohidrat terendah postmenopause sebanyak 52,15 gr dan asupan karbohidrat tertinggi sebanyak 399,90 gr.

Tabel 4. Hubungan Asupan KH dan IMT Premenopause dan Postmenopause

\begin{tabular}{|c|c|c|c|}
\hline & Pre & & Post \\
\hline & & IMT & IMT \\
\hline \multirow{3}{*}{ Asupan Karbohidrat } & $\mathrm{R}$ & -.028 & -.033 \\
\hline & (sig) & $.028^{*}$ & $.024^{*}$ \\
\hline & $\mathrm{N}$ & 6057 & 4787 \\
\hline
\end{tabular}

Berdasarkan tabel diatas dapat dilihat bahwa terdapat hubungan yang signifikan $(<0,05)$ antara asupan karbohidrat dan indeks massa tubuh pada wanita premenopause dan postmenopause di Indonesia.

Tabel 5. Pemodelan Hubungan Status Menopause, Asupan Karbohidrat dan Indeks Massa Tubuh

\begin{tabular}{clll}
\hline Model & B & Standar koef. $\beta$ & p-value \\
\hline (Constant) & 24,049 & - & 0,000 \\
Status Menopause & $-0,163$ & $-0,022$ & $0,020^{*}$ \\
Asupan KH & $-0,284$ & $-0,039$ & $0,000^{*}$ \\
${ }^{*}$ signifikan p $<0.05$ & & & \\
\hline
\end{tabular}

IMT = 24,049 - 0,163 (Status Menopause) 0,284 (Asupan Karbohidrat)

Dengan model persamaan ini maka dapat diprediksi bahwa setiap kenaikan satu tahun status menopause maka indeks massa tubuh akan berkurang 0,163. Selain itu dapat diprediksi setiap penambahan asupan 1 gram karbohidrat maka indeks massa tubuh akan menurun sebesar 0,28

Berdasarkan data yang didapat dari penelitian ini. Rata-rata indeks massa tubuh wanita premenopause usia 45- 49 tahun di Indonesia yaitu 23, 47 dengan standar deviasi 3,63. Sedangkan ratarata indeks massa tubuh untuk wanita postmenopause usia 50 - 54 tahun di Indonesia yaitu 23,32 dengan standar deviasi 3,63. Penelitian yang dilakukan di Vietnam, dilaporkan rata-rata indeks massa tubuh pada wanita dewasa umur $>18$ tahun sebesar 19,5 $\pm 1,9$. Berdasarkan Survey Konsumsi Thailand pada tahun 2010 individu wanita dewasa (18 - 70 tahun), rata - rata memilki indeks massa tubuh sebesar 23,1 $\pm 4,55$.

Berdasarkan hasil yang diperoleh, rata-rata asupan karbohidrat total wanita premenopause usia 45 - 49 tahun di Indonesia adalah sebesar 207,25+61,12 gram. Sedangkan rata-rata asupan karbohidrat total wanita postmenopause usia di 50 - 54 tahun di Indonesia adalah sebesar 198, 96 $\pm 66,43$ atau. Menurut data Riskesdas (2010) wanita di Indonesia umur 19 - 55 tahun rata-rata mengkonsumsi karbohidrat 224 gram (Balitbangkes, 2011). Berdasarkan Angka Kecukupan Gizi (2012) kecukupan karbohidrat pada wanita usia 30-49 adalah 323 gran dan pada wanita 50-64 tahun adalah 285 gram 
(Kemenkes, 2013). Sehingga asupan karbohidrat wanita premenopause dan postmenopause masih dibawah angka kecukupan yang dianjurkan. Survey Konsumsi Thailand pada tahun 2010 individu wanita dewasa (18 - 70 tahun), rata-rata mengkonsumsi karbohidrat sebesar 199,1 gr per hari (Jitnarin, 2010)

Berdasarkan hasil penelitian dan perhitungan uji statistik dengan uji korelasi pada wanita premnopause menunjukkan ada hubungan yang signifikan antara asupan karbohidrat dengan indeks tubuh, dengan nilai $\mathrm{p}=0,028(\mathrm{p} \leq 0,05)$. Kekuatan hubungan variabel asupan karbohidrat dan indeks massa tubuh ditunjukkan dengan nilai $r=-0,028$. Nilai Korelasi ini menunjukkan kekuatan hubungan antara kedua variabel tersebut negatif lemah. Sedangkan pada wanita postmenopause menunjukkan ada hubungan yang signifikan antara asupan karbohidrat dengan indeks massa tubuh, dengan nilai $\mathrm{p}=0,024$ $(\mathrm{p} \leq 0,05)$. Kekuatan hubungan variabel asupan karbohidrat dan indeks massa tubuh ditunjukkan dengan nilai $r=-0,033$. Nilai Korelasi ini menunjukkan kekuatan hubungan antara kedua variabel tersebut negatif lemah. Hubungan negatif artinya semakin tinggi asupan karbohidrat maka IMT semakin rendah. Hal ini mungkin terjadi karena terdapat variabel pengganggu yaitu serat yang tidak dihitung asupan seratnya. Selain itu pada penelitian ini tidak membedakan jenis karbohidrat kompleks dan karbohidrat sederhana.

Penelitian ini sejalan dengan penelitian pada orang dewasa di Kotamadya Padang yang menyatakan terdapat hubungan bermakna antara asupan karbohidrat dengan indeks massa tubuh $\quad(\mathrm{p}<$ 0,05) (Mourbas, 1997). Hal ini mungkin disebabkan oleh jenis karbohidrat yang dikonsumsi, dimana karbohidrat dibagi menjadi dua jenis yaitu karbohidrat kompleks atau karbohidrat sederhana. Karbohidrat sederhana lebih mudah dicerna dibandingkan karbohidrat kompleks.

Analisis regresi dilakukan bertujuan untuk mendapatkan model yang cocok (fit) dalam menggambarkan hubungan antara variabel dependen dan variabel independen. Selain itu nilai R Square pada permodelan ini sebesar 0,002 yang berarti kedua variabel independen ini menjelaskan variabel indeks massa tubuh sebesar 0,2\%. Hasil uji permodelan dapat menunjukkan bahwa koefisien beta pada usia sebesar -0,034 dan nilai koefisien beta asupan karbohidrat sebesar -0,284. Dengan demikian dari permodelan dapat diprediksi bahwa setiap kenaikan usia satu tahun maka indeks massa tubuh akan berkurang 0,034. Selain itu dapat diprediksi setiap penambahan 1 gram karbohidrat maka indeks massa tubuh menurun sebesar 0,284.

Model analisis regresi hanya mampu memprediksi nilai IMT sebesar 0,2\% ini berarti terdapat faktor lain yang mungkin mempengaruhi indeks massa tubuh pada wanita premenopause dan wanita postmenopause seperti aktivitas fisik, penyakit degeneratif, dan lain - lain.

Berdasarkan hasil uji analisis regresi variabel usia merupakan salah satu faktor yang mempengaruhi indeks massa tubuh karena berperan penting dalam menentukan pemilihan makanan. Selain itu pada usia premenopause dan postmenopause terjadi penurunan sistem persyarafan yaitu menurunya hubungan persyarafan, mengecilnya saraf panca indera. Sistem gastrointestinal, kehilangan gigi, indera pengecap menurun, esofagus melebar, rasa lapar menurun, peristaltik melemah dan timbul konstipasi, serta fungsi absropsi melemah. Sistem endokrin menurunya laju metabolisme (Nugroho, 2000).

Hal ini diperkuat dengan penelitian yang menyatakan bahwa usia menjadi prediktor yang kuat terhadap stunting dengan nilai $r$ square sebesar $0,88(\mathrm{p}<0,01)$ dan kekurusan dengan nilai $r$ square sebesar 0,33 ( $\mathrm{p}<0,01)$ (Mulugeta, 2009). Pada penelitian ini variabel asupan karbohidrat menujukkan adanya hubungan yang signifikan dengan indeks massa tubuh dan dapat mengurangi indeks massa tubuh pada wanita premenopause dan postmenopause di Indonesia. Hal ini kemungkinan terkait dengan asupan karbohidrat yang banyak dikonsumsi disini adalah karbohidrat kompleks yang mengandung serat sehingga kenaikan karbohidrat tidak menyebabkan kenaikan indeks massa tubuh. Jadi terdapat variabel serat yang mungkin menjadi variabel pengganggu dan tidak diteliti oleh peneliti, serta adanya penyakit komplikasi diabetes melitus, penyakit yang banyak dijumpai pada lansia, bisa jadi merupakan variabel pengganggu yang tidak diteliti. Sebagaimana diketahui penyakit diabetes melitus cenderung mengakibatkan penderita tampak lebih kurus walaupun dengan asupan karbohidrat yang tinggi.

Hasil penelitian ini sejalan dengan penelitian yang menyatakan bahwa asupan karbohidrat menjadi prediktor indeks massa tubuh dengan nilai $r^{2}$ sebesar 0,46 $(0<0,01)$ (Megan, 1999). Hasil penelitian NHANES asupan karbohidrat mampu menurukan berat badan, terutama jika mengkonsumsi karbohidrat kompleks yang banyak mengandung serat (Kant, 1995) Penelitian yang dilakukannya selama 4 tahun pada 120877 pada pria dan wanita di Amerika menyimpulkan asupan kentang menyebabkan penurunan berat badan sebesar 0,6 kg (Mozaffarian, 2011). 


\section{Simpulan dan saran}

Sampel pada penelitian ini berjumlah 10.844 orang, sampel wanita premenopause berjumlah 6.057 orang dan sampel wanita postmenopause 4.787 orang. Wanita premenopause tinggal di wilayah perkotaan sebanyak 3.540 orang dan perdesaan 2.517 orang, sedangkan pada wanita postmenopause tinggal di wilayah perkotaan sebanyak 2.733 orang dan perdesaan 2.054 orang. Rata-rata usia wanita premenopause adalah 46 tahun 8 bulan, dan rata-rata usia wanita postmenopause adalah 51 tahun 7 bulan. Rata-rata indeks massa tubuh wanita premenopause adalah 23,47 dan rata-rata indeks massa tubuh wanita postmenopause 23,32. Rata-rata asupan karbohidrat wanita premenopause sebesar 207,25 gram dan rata-rata asupan karbohidrat wanita postmenopause sebesar 197,10 gram. Hasil analisa korelasi diketahui ada hubungan negatif $\mathrm{r}=-0,028$ dan signifikan $(p=0,028)$ antara asupan karbohidrat dan indeks massa tubuh pada wanita premenopause, sedangkan pada wanita postmenopause diketahui ada hubungan negatif $\mathrm{r}=-0,033$ dan signifkan $(p=0,024)$ antara asupan karbohidrat dan indeks massa tubuh pada wanita postmenopause. Sehingga wanita premenopause dan postmenopause diharapkan meningkatkan konsumsi KH terutama KH kompleks. Status menopause merupakan variabel terkuat yang mempengaruhi indeks massa tubuh pada wanita premenopause dan postmenopause.

\section{Daftar Rujukan}

Badan Litbang Kesehatan Departemen Kesehatan.(2011). Riset Kesehatan Dasar (Riskesdas)2010: Laporan Nasional. Jakarta: Badan Litbangkes Depkes

Fernandez, Alonso et.al (2010).Obesity Is Related To Increased Menopausal Symptoms Among Spanish Women. Journal Menopause International Vol. 16 No. 3 September 2010.

Jitnarin, Nattine, Vongsvat Kosulwat, et al. (2010). Risk Factor for Overweight and Obesity among Thai Adults: Result of the National Thai Food Consumption Survey.Mdpi Journal nutrients $2010 ; 2 ; 60$ 74 .

Kant AK, Graubard BI, Schatzkin A, Ballard-Barbash R. (1995).Proportion Of Energy Intake From Fat Andsubsequent Weight Change In The NHANES I Epidemiologic Follow-Up Study. Am J Clin Nutr1995;61(1):11-17.

Kementrian Kesehatan RI (2007). Profil Kesehatan Indonesia 2005.Departemen Kesehatan RI, Jakarta.

Kementerian Kesehatan Republik Indonesia. (2013).Pedoman Pelayanan Gizi Rumah Sakit . Jakarta : Direktorat Jenderal Bina Gizi Dan Kesehatan Ibu Dan Anak.

Kim K, Yun SH, Choi BY, \& KIM MK. 2008. Cross- Sectional Relationship Between Carbohydrate, Glycemic Index, Glicemic Load, and Risk Of The Metabolic Korean Population. British Journal og Nutrition, 100, 576-58.

Dietary

Syndrome in a

Lambrinoudaki I, Brincat M, Erel CT, Gambacciani M, Moen MH, Schenck-Gustafsson K, et al. EMAS position statement: managing obese postmenopausal women.Journal Maturitas. 2010;66(3): 323-

Megan Et Al (1999). Energy Intake And Meal Portions: Associations With BMI Percentile In U.S. North American Association For The Study Of Obesity (NAASO)

Mozaffarian (2011). Changes In Diet and Lifestyle and Long- Term Weight gain in Women and Men. The New England Journal Of Medicine.

Mulugeta A., Hagos F., Stoecker B., Kruseman G., Linderhof V.\& Abraha Z. et al (2009): Nutritional Status of Adolescent Girls from RuralCommunities of Tigray, Northern Ethiopia; Ethiopia J Health Dev, 23(1): 5-11.

Mourbas, Iswanelly (1997). Hubungan Jumlah Konsumsi Makanan Terhadap IMT Orang Dewasa di Kotamadya Padang 1996: Fakultas Kesehatan Masyarakat, Universitas Indonesia. 
Nugroho. 2000. Keperawatan Gerontik, Jakarta.EGC

Noriko, Nita . 2014. Diversifikasi Pangan Sumber Karbohidrat Canna edulis Kerr. (Ganyong) . Jurnal ALAZHAR INDONESIA SERI SAINS DAN TEKNOLOGI, Vol . 2, No. 4, September 2014

Qalsum, Umi. 2015. Analisis Kadar Karbohidrat, Lemak Dan Protein Dari Tepung Biji Mangga (Mangifera Indica L) Jenis Gadung . Jurnal Akademika Kimia Volume 4, No. 4, 2015 